\title{
DESIGN AND CONSTRUCTION OF A FLAX RUBBING DESEEDER
}

\begin{abstract}
Abdou S. El-Ashry *
ABSTRACT

A roller flax deseeder was designed, constructed and tested to evaluate its ability to deseed flax without causing appreciable stalk damage. The deseeder was tested and evaluated at El-Gemmiza Agricultural Research Station, El-Gharbia Governorate under four revolving speeds for upper rollers $(2.93,4.69,6.45$ and $8.21 \mathrm{~m} / \mathrm{s})$, three revolving speeds for lower rollers $(0.67,0.97$, and $1.2 \mathrm{~m} / \mathrm{s})$ and three clearance between upper and lower rollers $(1.5,2.5$ and $3.5 \mathrm{~cm})$. Machine productivity, stalk losses, power requirements and deseeding efficiency had been determined. Optimum values for the operation conditions were obtained at lower rollers speed of $0.97 \mathrm{~m} / \mathrm{s}$ and upper roller speeds of $8.21 \mathrm{~m} / \mathrm{s}$ (kinematics parameter of 8.46) and clearance between lower and upper rollers of 2.5 $\mathrm{cm}$. Where as given the best results of deseeding efficiency (99.65\%). Regarding the effect of threshing system on criterion costs, results show that the rubbing deseeder system recorded the minimum values of criterion costs (82.72 L.E/ton) comparing with the other threshing systems (205.67 and 254.08 L.E/ton) for traditional method and impact thresher respectively.
\end{abstract}

\section{INTRODUCTION}

lax ( Linum usitatissimum ) is considered one of the most
important economical crops due to, it is a source of heavy (idle)
oil and special fibers used in different scopes of industry. The cultivated area in Egypt reach up to 70000 feddan yearly.

Nowadays, there is an intention to increase the flax fiber exportation as well as local industry which defend to a great extent on the quality of fiber. Deseeding is one of the most important operation in fiber production. Use of conventional threshers designed primarily for cereal grains, which threshers seed or grain from plant material primarily by impact, result separation problems and crushing of flax stalk.

*Senior Researcher, Agric. Eng. Res. Ins., Agric. Res. Center, Dokki, Egypt. 
Kepner et al. (1978) mentioned that, threshing may be accomplished by: a) impact of a fast moving member upon the material, b) rubbing, c) squeezing pods, d) a combination of two or more of these actions or e) some other methods of applying the required forces. Bainer et al. (1982) stated that, flax crop can be threshed by using one rubber covered roll and one steel roll. The upper roll is spring-loaded and is driven about 10 percent faster than the lower roll to give a rubbing action in addition to the squeezing effect. Adjustable stops on the spring loaded roll are set to provide a minimum clearance sufficient for the passage of seeds without damage. Klenin et al. (1985) stated that, the flax seed are removed from their pods by crushing and grinding them between husking rolls rotating in opposite direction.

Badawy (2002) and EL-Ashry et al. (2006) reported that, the minimum seed losses ( $4.16 \%$ ) was recorded at $11.25 \%$ moisture content.

EL-Ashry et al. (2003) investigated and evaluated the comparative economic benefits of partial and complete mechanized flax threshing practices. They found that, the complete mechanized system recorded the maximum values of criterion costs 254.08 L.E/ton because of the maximum straw losses $24.35 \%$ occurred under complete mechanized systems. That indicated cause the flax threshing still carried out manually or trampling by tractor wheel. They recommended the need to design a deseeder to suit flax crop accomplished by rubbing to obtain low levels of flax stalks damage.

The main objectives of the present study as following :

- Designing and testing a rubbing deseeder suitable for flax crop and applies the theory of frictional rubbing force.

- Studying the effect of some processing conditions such as, upper and lower roller speeds and clearance on deseeder productivity and deseeding efficiency.

\section{MATERIALS AND METHODS}

\section{The manufactured deseeding machine :}

The designed deseeding machine " first prototype "was constructed and tested at EL-Gemmiza Research Station EL-Gharbia Governorate. The view of the deseeder is shown in Fig.(1) .The machine is designed for 
deseeding flax crop where the flax seeds are to removed from their pods by crushing and grinding them without causing the stalks damage.

The main specifications of this machine are : total height $149 \mathrm{~cm}$, width $73 \mathrm{~cm}$, length $216 \mathrm{~cm}$ and total mass $465 \mathrm{~kg}$. it consists mainly of four pair of rollers, each lower roll is held against the upper roll by spring pressure which can be regulated. Each roller was fabricated from hard steel at length of $48 \mathrm{~cm}$, diameter of $11.2 \mathrm{~cm}$ and weight of $12 \mathrm{~kg}$. Eight springs (10 cm free length, $2 \mathrm{KN}$ load at $50 \%$ deflection) at the corners of the upper rollers provided the force compression $\left(318 \mathrm{n} / \mathrm{m}^{2}\right)$ required by adjust the gap clearance between two rollers. The lower rollers were adjusted to move slower than the upper rollers to provide the rubbing action. The flax crop is fed at first pair rollers and is discharged from the rear end of the machine.

\section{Theory of machine operation : ( Basic machine operation ):}

Threshing may be accomplished by : a) impact of a fast moving member upon the material, b) rubbing, c) squeezing pods. d) a combination of two or more of these actions ( Kepner et al., 1978).

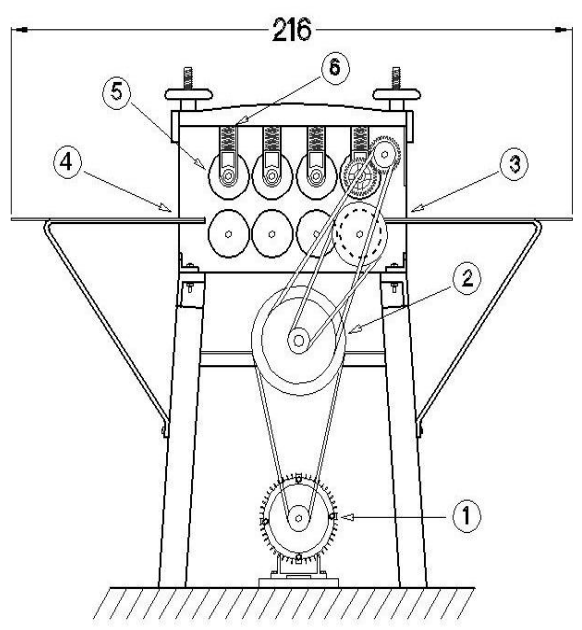

ELEVATION

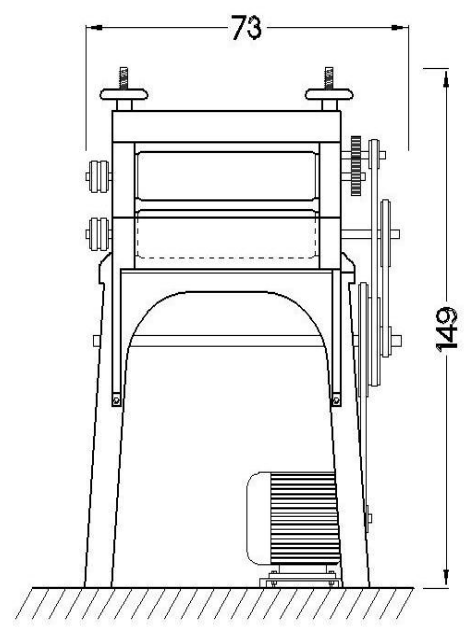

SIDE VIEW
1- Engine.

2- Main driving pulley.

3- Inlet of crop.

4- Outlet of straw.

5- Deseeding rollers.

6- Springs.

Dimensions in $\mathrm{cm}$

Fig.(1) : Elevation and side view of the rubbing deseeder. 
The operation theory of this deseeding machine depends upon frictional rubbing forces by passing material between four pair of rollers. The rubbing mode was chosen for the design based on the physical characteristics of the capsules and the results from the impact tests using ( EL-Ashry et al., 2003). The lower rollers were adjusted to move slower than the upper rollers to provide the rubbing action causes the capsules to be crushed and removed from the stalks.

\section{Source of power:}

The power source utilized in this machine is an electric motor of $10 \mathrm{Hp}$ $(7.46 \mathrm{KW})$ with a rotating speed of $970 \mathrm{rpm}$ and a potential difference $380 \mathrm{v}$. The power is transmitted from the source to the machine by means of pulley and V-belt as shown in Fig.(1).

The used flax crop was of variety (Sakha 1). The physical characteristics were estimated for both plants and seeds. As shown in the following table:

Table (1): The measured physical properties for flax crop (Sakha 1):

\begin{tabular}{|c|c|}
\hline Physical characteristics & Average value \\
\hline Plant height, $(\mathrm{cm})$ & 101.5 \\
\hline Technical length, $(\mathrm{cm})$ & 82.45 \\
\hline Stem diameter, $(\mathrm{cm})$ & 1.75 \\
\hline Number of capsules per plant & 10.05 \\
\hline Capsule diameter, $(\mathrm{mm})$ & 6.5 \\
\hline Seed yield, $(\mathrm{kg} / \mathrm{Fed})$ & 600 \\
\hline Straw yield, $($ ton/Fed $)$ & 3.5 \\
\hline
\end{tabular}

\section{Procedures and measurements :}

The flax crop was harvested manually, the flax plants were left in the field from 3 to 4 days in small piles for natural drying and later gathered into large heaps in the threshing yard. Before any tests, flax crop was sun-dried for a few hours to extract the moisture that the crop was picked up during the night since the crop was not stored in an enclosed buildings.

Before threshing, the capsules/plant ratio were calculated, and the capsules moisture content levels were determined by oven drying 
method. After threshing, the unthreshed capsules were removed manually.

\section{Study parameters :}

The performance of the designed deseeder was evaluated under the following parameters :

- Linear speed of faster ( upper ) rollers ( 2.93,4.69,6.45 and 8.21 $\mathrm{m} / \mathrm{s})$.

- Linear speed of lower rollers ( 0.67, 0.97 and $1.2 \mathrm{~m} / \mathrm{s}$ ).

- Clearance between the upper and the lower rollers (1.5, 2.5 and $3.5 \mathrm{~cm}$ ).

All experiments were conducted at capsules moisture content of $12.25 \%$. An average of three replicates of this procedure was taken. Then the machine-feeding rate $(\mathrm{kg} / \mathrm{h}$ ) and energy requirements ( Kw.h/ton ) were estimated for each test. Also, the deseeding efficiency and cost estimated.

\section{Deseeding efficiency :}

It was calculated according to the equation of Mishra and Desta, 1990 as follows :

Deseeding efficiency $=100-\left[\frac{\text { Weight of undeseed seeds in sample }}{\text { Total weight of seeds in sample }} \times 100\right]$

Undeseed seed losses :

Undeseed seed losses were calculated according to the following formula :

Undeseed seed losses $=\frac{\text { Weight of seed losses with the straw }}{\text { Total weight of seeds }} \times 100$

Stalks losses:

Stalks losses were calculated according to the following formula:

$$
\text { Stalkslosses }=\frac{W_{s p s}}{W_{s t}} \chi 100
$$


Where:

$\mathrm{W}_{\text {sps }}=$ weight of split portion of stalks during threshing

$\mathrm{W}_{\mathrm{st}}=$ total weight of stalk rather than capsules

Stalk damage percentage $\left(S_{d}\right)$ :

$$
S_{d}=\frac{D_{s}}{T_{s}} \times 100
$$

Where :

$\mathrm{D}_{\mathrm{s}}=$ The mass of damaged stalks, $(\mathrm{kg})$.

$\mathrm{T}_{\mathrm{s}}=$ The total mass of stalks, $(\mathrm{kg})$.

\section{Estimation of energy requirements :}

Both ammeter and voltmeter were used for measuring current and potential difference respectively with an accuracy of $\pm 1 \%$. Then, the power was estimated using the knowledge of line current in Amperes and potential difference in volts. The actual power of the machine ( P ) was estimated according to the following equation ( Lock Wood and Dunstan, 1971 ) :

$$
P=\sqrt{3} \cdot I \cdot V \cdot \eta \cdot \cos \theta \quad \ldots \ldots . \text { watt }
$$

Where :

$$
\begin{array}{ll}
\mathrm{I} & =\text { Line current strength in amperes. } \\
\mathrm{V} & =\text { Potential difference ( voltage ), equal to } 380 \mathrm{v} . \\
\eta & =\text { Mechanical efficiency, assumed ( } 95 \%) . \\
\cos \theta & =\text { Power factor (was taken as } 85 \%) .
\end{array}
$$

Energy requirement ( $\mathrm{kw} . \mathrm{h} /$ ton ), was calculated by dividing the consumed power ( $\mathrm{kw}$ ) by the feeding rate ( ton / $\mathrm{h}$ ).

\section{Total cost :}

Total cost was estimated according to the assumption and procedures given by Hunt, 1983 and Bowers, 1987.

Criterion cost $($ L.E $/$ ton $)=$ operation cost $($ L.E / ton $)+$ seed losses cost ( L.E / ton ) + straw losses cost ( L.E / ton ).

\section{RESULTS AND DISCUSSIONS}

In order to evaluate the deseeder performance during deseeding flax crop, the different criteria of threshing operation, such as quality properties of 
yield, stalk damage percentage and other factor related to deseeding efficiency, seed losses percentage, machine productivity and energy requirements during deseeding operation were taken into consideration.

\section{Stalk losses :}

Increasing clearance between the upper and the lower roller, decreased stalk losses percentage at all upper and lower roller speeds. Increasing clearance from $1.5,2.5$ to $3.5 \mathrm{~cm}$, decreased the percentage of stalk losses from 5.25,4.07 to $2.53 \%$ respectively at upper and lower rollers speed of ( 8.21 and $0.67 \mathrm{~m} / \mathrm{s}$ ) respectively. The same trend was obtained at different operation conditions. Increasing upper roller speed increased the percentage of stalk losses at all lower roller speed and clearances. As indicated in figure (2). Increasing upper roller speed from $2.93,4.69$ and 6.45 to $8.21 \mathrm{~m} / \mathrm{s}$, increased the percentage of stalk losses from $2.28,2.87$ and 4.52 to $5.25 \%$ respectively, at $0.67 \mathrm{~m} / \mathrm{s}$ lower roller speed and $1.5 \mathrm{~cm}$ clearance. This may due to the increasing in the frictional force.

\section{Deseeder productivity :}

Machine capacity was increased by increasing clearance between upper and lower roller at all upper and lower roller speeds as shown in figure (3). Increasing clearance from $1.5,2.5$ to $3.5 \mathrm{~cm}$, increased the machine capacity from $0.405,0.519$ to 0.625 ton $/ \mathrm{h}$ respectively at upper and lower roller speed of ( 2.93 and $0.67 \mathrm{~m} / \mathrm{s}$ ) respectively. Increasing roller speed leads to increase machine capacity. Increasing roller speed from 2.93 to $8.21 \mathrm{~m} / \mathrm{s}$, leads to increase machine capacity from 0.405 to 0.541 , from 0.512 to 0.612 and from 0.633 to 0.790 ton / h at clearance of 1.5 $\mathrm{cm}$ and lower roller speeds of $0.67,0.97$ and $1.2 \mathrm{~m} / \mathrm{s}$. The observations reported in Fig. (3) show the effect of roller speeds, clearance between upper and lower roller on deseeder productivity.

The data reveled that, at any upper roller speed, the productivity rate of deseeder increased as the lower roller speed and clearances increased. On the other words, at $8.21 \mathrm{~m} / \mathrm{s}$ upper roller speed, the results indicated that, increasing lower roller speed from 0.67 to $1.2 \mathrm{~m} / \mathrm{s}$ cause a corresponding increase in deseeder productivity from 0.541 to 0.790 , from 0.628 to 0.968 and from 0.706 to 1.072 ton / $\mathrm{h}$ at clearance between upper and lower roller of $1.5,2.5$ 

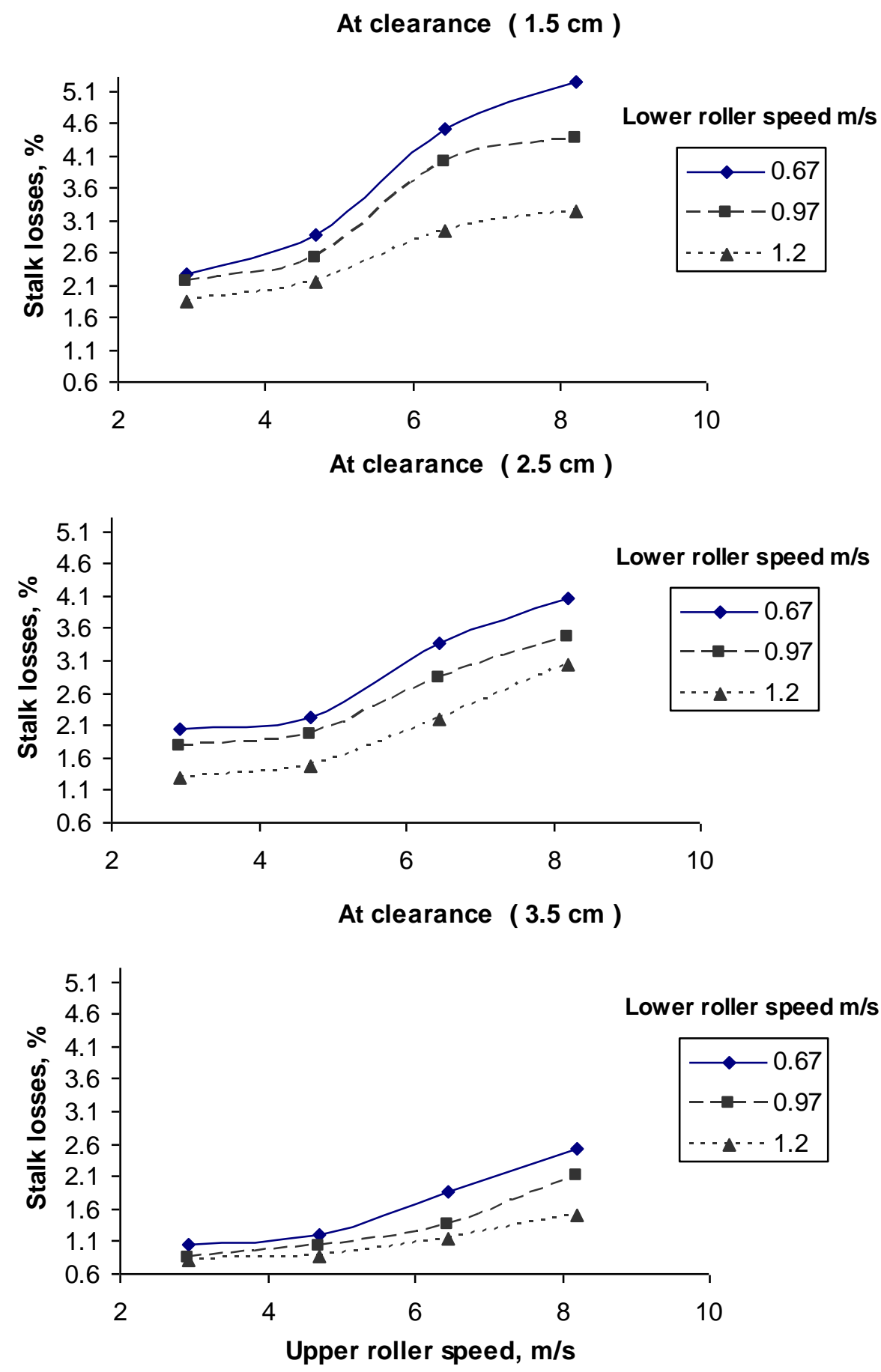

Fig. (2 ) : The effect of upper and lower roller speeds on stalk losses at different clearances. 

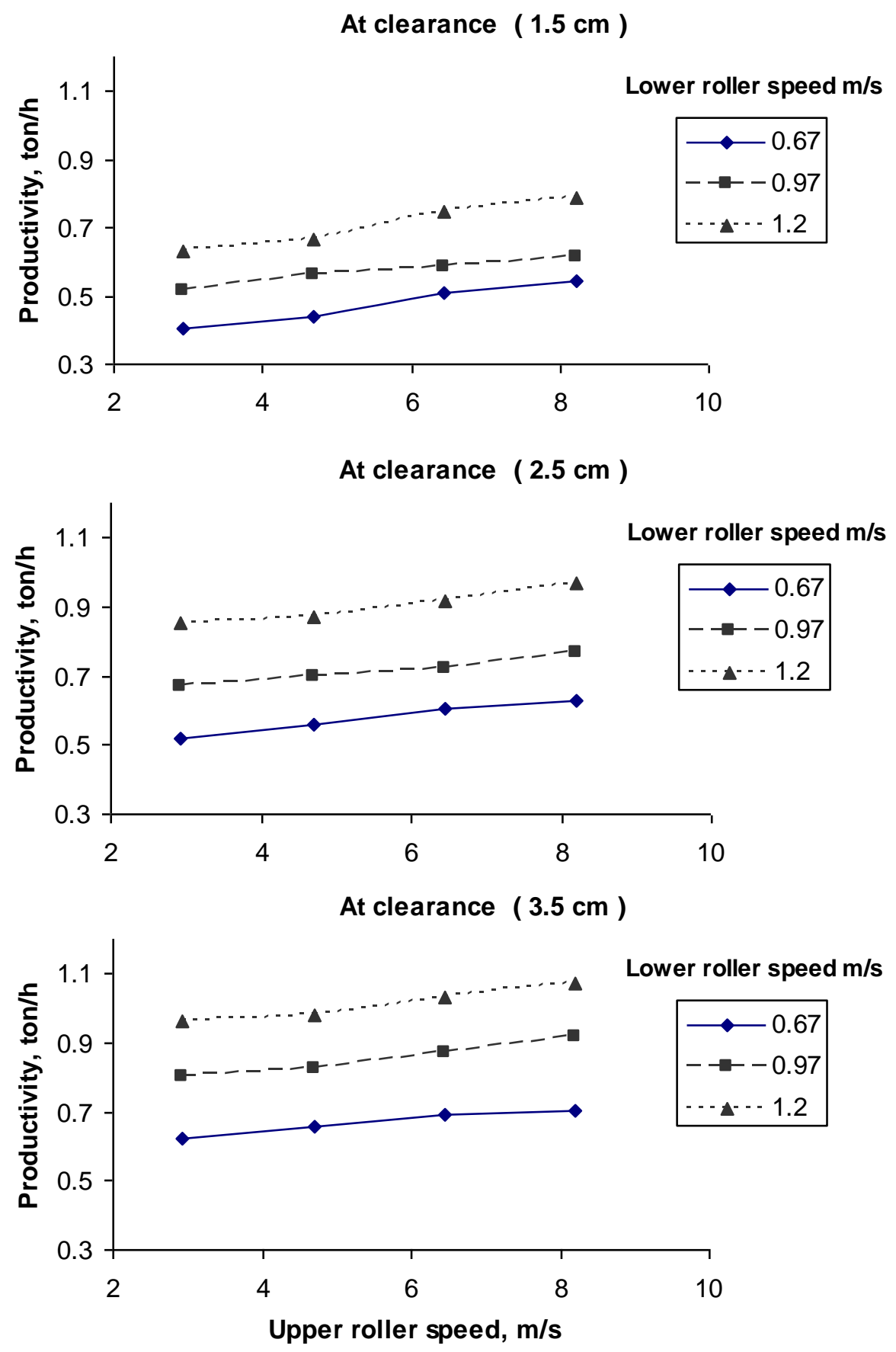

Fig. ( 3 ) : The effect of upper and lower roller speeds on productivity at different clearances. 
and $3.5 \mathrm{~cm}$ respectively. This increase in deseeder productivity with the increase in roller speeds and clearances may be attributed to the decrease in the time needed for threshing capsules. Also, it is noticed that, the machine productivity at the minimum tested clearance, lower roller speed and upper roller speed $(1.5 \mathrm{~cm}, 0.67 \mathrm{~m} / \mathrm{s}$ and $2.93 \mathrm{~m} / \mathrm{s}$ ) was 0.405 ton / $\mathrm{h}$. The machine productivity increased 2.5 times $(1.072 \mathrm{ton} / \mathrm{h})$ at the maximum tested clearance, lower roller speed and upper roller speed ( $3.5 \mathrm{~cm}, 1.2 \mathrm{~m} / \mathrm{s}$ and $8.21 \mathrm{~m} / \mathrm{s}$ respectively ).

\section{Deseeding efficiency :}

The data reported in Fig.(4) show the effect of upper and lower roller speeds and clearance between upper and lower rollers on deseeding efficiency.

The data revealed that, at any lower roller speed and the clearance between upper and lower rollers, the deseeding efficiency of deseeder increased as the upper roller speed increased. As an example, at $1.5 \mathrm{~cm}$ clearance increasing upper roller speed from 2.93 to $8.21 \mathrm{~m} / \mathrm{s}$ causes an increase in the deseeding efficiency from 97.27 to $99.65 \%$ and from 96.85 to $99.38 \%$ and from 95.33 to $98.68 \%$ at lower rollers speed of $0.67,0.97$ and $1.2 \mathrm{~m} / \mathrm{s}$ respectively. The average increase in deseeding efficiency due to increasing roller speed was $2.83 \%$. High roller speed leads to high deseeding efficiency because it caused an increase in the friction between rollers and capsules.

When the clearance between upper and lower rollers increased from 1.5 to $3.5 \mathrm{~cm}$, tended to decrease deseeding efficiency from 96.48 to 92.65 $\%$, from 97.25 to $93.68 \%$, from 98.05 to $94.2 \%$ and from 99.24 to 95.33 $\%$ at upper roller speed of $2.93,4.69,6.45$ and $8.21 \mathrm{~m} / \mathrm{s}$. The average reduction in deseeding efficiency due to increasing clearance was 3.79 $\%$. High clearance leads to small deseeding efficiency, because it caused an increase in feeding rate, which led to a decrease in the friction between the rollers and capsules.

The maximum deseeding efficiency ( $99.65 \%$ ) was recorded at $8.21 \mathrm{~m} / \mathrm{s}$ upper roller speed, $0.67 \mathrm{~m} / \mathrm{s}$ lower roller speed ( kinematics' parameter of 8.46 ), $1.5 \mathrm{~cm}$ clearance between upper and lower rollers. 


\section{Power and Energy Requirements :}

Table (2) and Fig.(5) show the power and energy requirements as affected by different upper and lower roller speeds and clearances between upper and lower rollers.

It is remarkable that the power requirements for deseeding operation increased as the upper and lower roller speeds increased, while it decreased with increasing clearance between upper and lower rollers. On the other words, at $3.5 \mathrm{~cm}$ clearance between upper and lower roller, the results indicated that increasing roller speeds from 2.93 to $8.21 \mathrm{~m} / \mathrm{s}$ cause a corresponding increase in the deseeder power consumption from 2.78 to 3.84 , from 3.0 to 4.30 and from 3.42 to $4.65 \mathrm{kw}$ at lower roller speeds of $0.67, .97$ and $1.2 \mathrm{~m} / \mathrm{s}$ respectively.

Table ( 2 ) : Power requirements as affected by different upper and lower roller speeds and clearances .

\begin{tabular}{|c|c|c|c|c|c|}
\hline \multirow{2}{*}{$\begin{array}{c}\text { Clearance, } \\
\mathrm{cm}\end{array}$} & \multirow{2}{*}{$\begin{array}{c}\text { Lower roller } \\
\text { speed, } \\
\mathrm{m} / \mathrm{s}\end{array}$} & \multicolumn{4}{|c|}{ Upper roller speed $\mathrm{m} / \mathrm{s}$} \\
\cline { 3 - 6 } & & 2.93 & 4.69 & 6.45 & 8.21 \\
\cline { 3 - 6 } & 0.67 & 3.24 & 3.37 & 4.00 & 4.49 \\
\hline \multirow{3}{*}{1.5} & 0.97 & 3.72 & 4.16 & 4.40 & 5.00 \\
& 1.20 & 3.85 & 4.33 & 5.09 & 5.78 \\
\hline \multirow{3}{*}{2.5} & 0.67 & 3.10 & 3.41 & 3.69 & 4.35 \\
& 0.97 & 3.46 & 3.91 & 4.21 & 4.69 \\
& 1.20 & 3.64 & 4.25 & 5.00 & 5.58 \\
\hline \multirow{3}{*}{3.5} & 0.67 & 2.78 & 3.04 & 3.31 & 3.84 \\
& 0.97 & 3.00 & 3.41 & 3.80 & 4.03 \\
& 1.20 & 3.42 & 3.98 & 4.35 & 4.65 \\
\hline
\end{tabular}


It is clear that, energy requirements for deseeding operation decreased as the lower roller speed and clearance increased, while it increased with increasing upper roller speeds As an example, at $8.21 \mathrm{~m} / \mathrm{s}$ upper roller speed, increasing lower roller speed from 0.67 to $1.2 \mathrm{~m} / \mathrm{s}$ cause decrease in the deseeder energy requirement from 10.68 to 7.32 , from 6.93 to 6.43 and from 5.44 to $4.71 \mathrm{kw} . \mathrm{h} / \mathrm{t}$ at clearances of $1.5,2.5$ and $3.5 \mathrm{~cm}$ respectively. High lower roller speed lead to small deseeder energy requirement, because it caused an increase in the deseeder productivity.

The case of greatest energy requirements ( $10.68 \mathrm{kw} \cdot \mathrm{h} / \mathrm{ton})$ recorded at $8.21 \mathrm{~m} / \mathrm{s}$ upper roller speed and the small clearance $1.5 \mathrm{~cm}$, while the case of smallest energy requirements recorded at the large lower roller speed $1.2 \mathrm{~m} / \mathrm{s}$ and the large clearance $3.5 \mathrm{~cm}$. The average reduction in energy requirements between these two cases were $55.8 \%$.

\section{Economic evaluation :}

The cost of flax threshing using the designed deseeder was compared with that of the traditional method (trampling by tractor) as well as threshing by impact thresher.

The machine cost per hour includes the fixed and variable costs for the machine and the motor. It was found to be $25 \mathrm{~L}$.E./ $\mathrm{Mg}$ at the optimum operating conditions (8.46 kinematics' parameter and $2.5 \mathrm{~cm}$ clearance). The operating cost of deseeding by traditional method and impact thresher were 28 and $25 \mathrm{~L} . \mathrm{E} / \mathrm{Mg}$ respectively.

The previous comparison may mislead the reader in some way because the seed and straw losses of each system differ from each other. To overcome this difficulty the losses of each system has been considered. It was believed that the criterion cost would be much better and actually represents the suitability of different systems. Regarding the effect of threshing system on criterion costs, results show that the rubbing deseeder system recorded the minimum values of criterion costs $(82.72$ L.E/ton) comparing with the other threshing systems (205.67 and 254.08 L.E/ton) for traditional method and impact thresher respectively. 
At clearance $(1.5 \mathrm{~cm})$
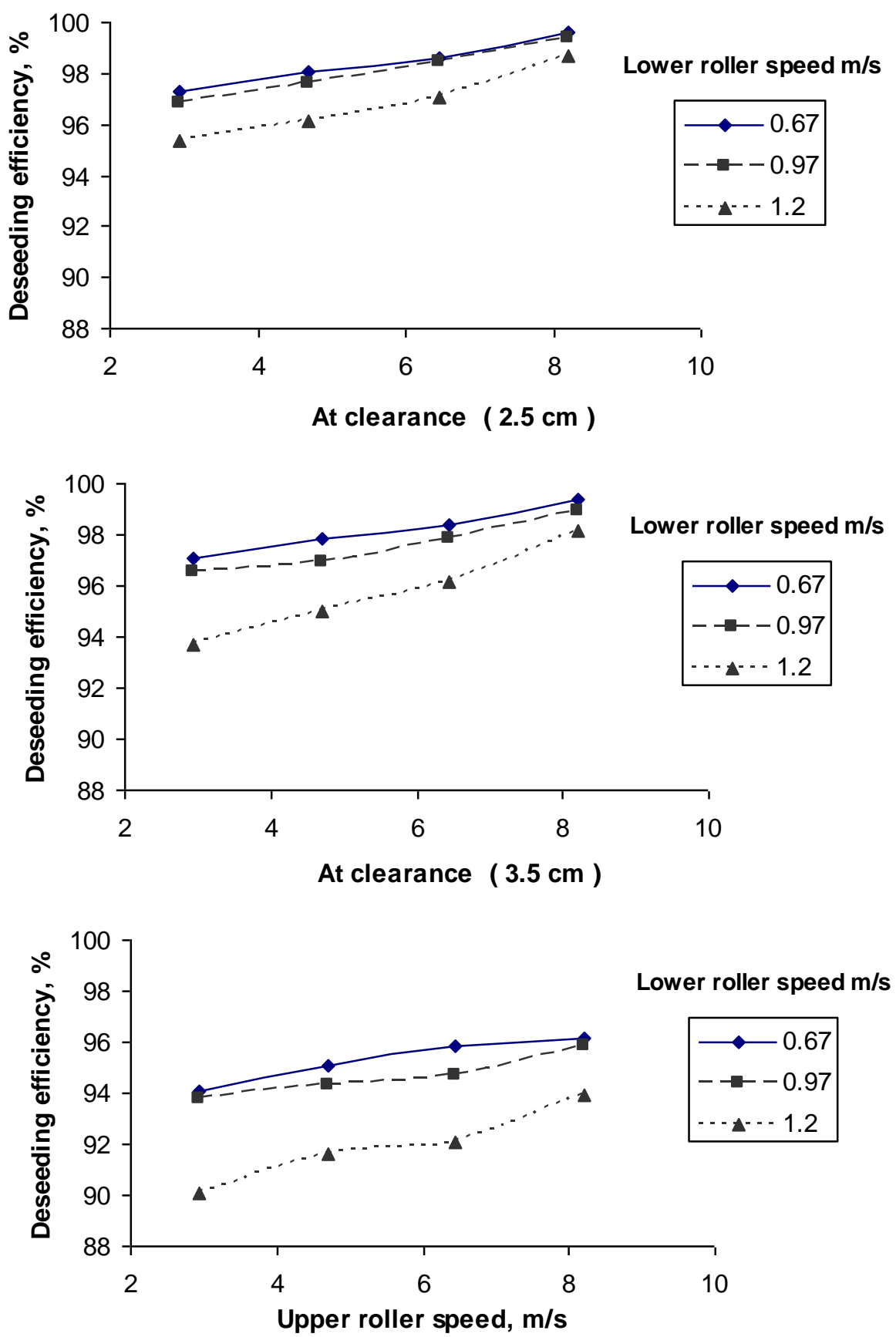

Fig. (4) : The effect of upper and lower roller speeds on deseeding efficiency at different clearances. 

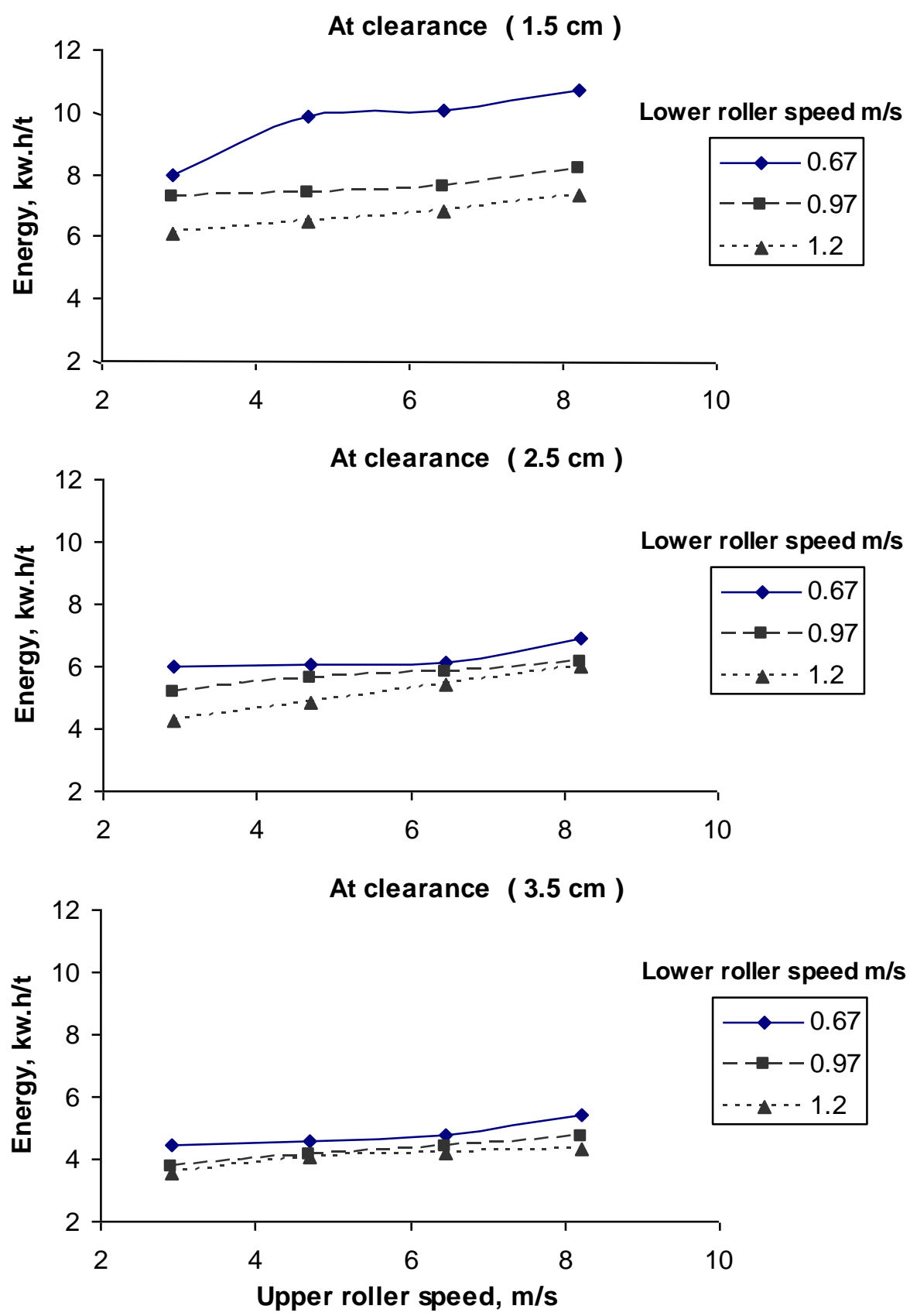

Fig. (5) : The effect of upper and lower roller speeds on energy requirements at different clearances. 


\section{CONCLUSION}

It has bean observed that, damage to stem flax during the deseeding may be reduced through the use of roller deseeder to provide a more gentle deseeding action. Using designed machine reduced broken and damaged stem of flax and maintained the high quality of flax fibers.

The optimum operation conditions for the deseeder were found to be as follows : upper roller speed $8.21 \mathrm{~m} / \mathrm{s}$, lower roller speed $0.97 \mathrm{~m} / \mathrm{s}$ ( kinematics' parameter of 8.46 ) and clearance between lower and upper roller of $2.5 \mathrm{~cm}$ where as given the best results of productivity rate, energy consumption and deseeding efficiency.

\section{REFERENCES}

Badawy, M.E. (2002). Modification and evaluation of paddy rice thresher to suit flax designing. Misr J. Ag. Eng, 19 (4): 881-900.

Bainer R., Kepener R.A. and Barger E.L. (1982) Principles of farm machinery Willey and sons inc. New York.

Bowers, W. (1987). Fundamentals of machine operation. Machinery Management Text Book. Deere and Company Moline. :91.

EL-Ashry A.S., A. EL-Rayes, G.R. Gamea (2003). " A comparative study of flax threshing system and their effects on yield components quality “ Misr J. Ag. Eng. 20 (3) pp 691 - 701.

El-Ashry A.S.: O.A. Omar and E.H. Musa (2006). Improvement of tractor performance in respect of increasing threshing efficiency of flax crop. Misr J. Ag. Eng, 23 (3): 532-548.

Hunt, D. ( 1983). Farm power and machinery management. Iowa St. U. Press. Ames, Iowa, $8^{\text {th }}$ edition.

Kepner,R.A.; R.Bainer and E.L.Barger (1978). Principles of farm machinery, $3^{\text {rd }}$.,A.VI $\mathrm{Pb}$. Co., Inc, Westport, Connecteut, U.S.A.

Klenin, N.I.; popover, I.F and Sakum, V, A (1985) Agricultural machines, Amerind puble. Co. PVT., New Delhi,: 400-418.

Lockwood, F.B. and R. Dunstan (1971). Electrical engineering principles. Meinemann Educational Books. Ltd. London.

Mishra, T.N. and E.Desta (1990). Development and performance evaluation of sorghum thresher. Ag. Mech. In ASIA, 21 (3), PP: 33-37. 


\section{الملخص العربيى}

\section{تصميم وتصنيع آلة لهـير الكتان بالاحتكاك}

\section{* عبده شوقي العثري}

محصول الكتان بعتبر ثناني محاصيل الألياف في العالم بعد القطن من حيث المساحة المنزرعة

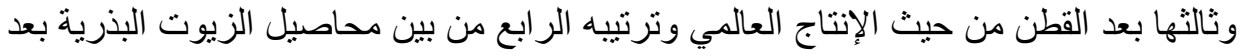

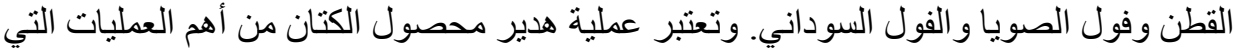
تؤثر بشكل كبير في إنتاجية المحصول وجودة الألياف و البذور و التي ماز الت تتم بالطرق اليدوية و البدائية سواء بضرب الكبسولات على حجر أو بمرور الجرار على المحصول بعد وضعه في الجرن على ارض صلبة وتتقية القش بعد مرور الجرار عليه مما يؤدى إلى الوصول إلى فقد في

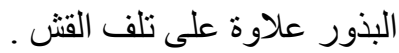
وفي الفترة الأخيرة تم استير اد أو تصنيع الكثير من آلات الدراس والتذرية تعتمد في نظرية

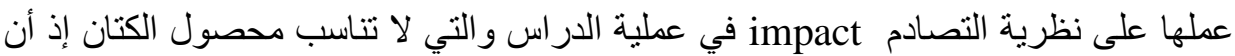
إنتاج ألياف جيدة يتطلب عدم تكسير أو تلف أعواد الكتان بالإضافة إلى أنها تتطلب قدره كبيره

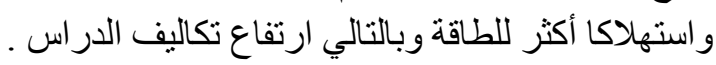
و عليه تتمثل هذه الدر اسة في تصميم وتصنيع و اختبار الة لهدير محصول الكتان تعتمد في عملها على قوى الفرك الاحتكاكي (frictional rubbing force) وذللك بمرور المحصول ولئ ولين أربعة

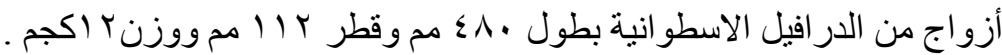

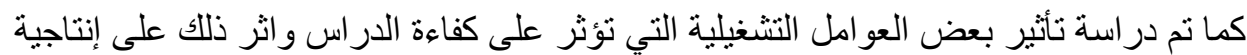
الآلة (طن/س) واستهلاك الطاقة (كيلو وات .س/طن) واشتملت الدراسة على أربعة مستويات

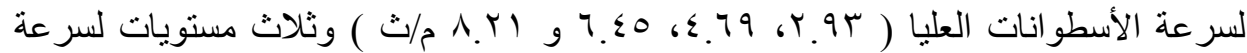

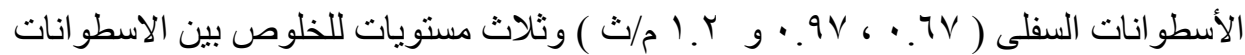

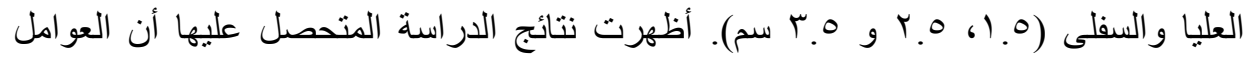

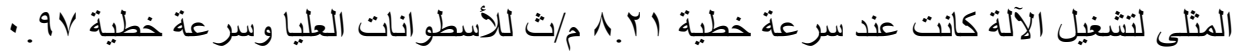

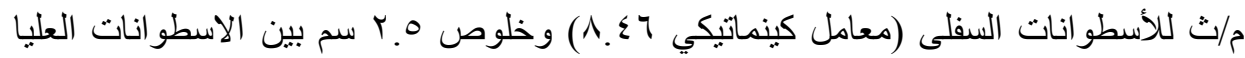

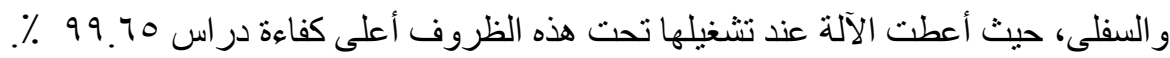

